\title{
Sexual dimorphism in response to herbivory and competition in the dioecious herb Spinacia oleracea
}

\author{
Marina Pérez-Llorca • Julia Sánchez Vilas
}

Received: 4 July 2018/ Accepted: 8 December 2018/Published online: 16 January 2019

(C) The Author(s) 2019

\begin{abstract}
Sexual dimorphism is common in dioecious plant species and is usually attributed to different cost of reproduction associated with male and female functions. Differences in growth and performance between male and female plants may be accentuated under stress, potentially leading to sex-ratio biases and affecting population growth. Environmental stress involves multiple factors that often occur simultaneously. Among different stress combinations that occur in field conditions, competition and herbivory and their interaction are key biotic factors that can affect plant growth and performance. Here, we conducted a glasshouse experiment in Cardiff, UK, using the cultivated spinach, Spinacia oleracea, as a model system to study sexual dimorphism in intra- and interspecific competitive ability and in response to herbivory by a generalist herbivore Helix aspersa. We found stronger inter- than intra-specific competition: growth (above-ground biomass) and chlorophyll
\end{abstract}

Communicated by Lauchlan Fraser.

M. Pérez-Llorca

Department of Evolutionary Biology, Ecology and Environmental Sciences, Faculty of Biology, University of Barcelona, Av. Diagonal 643, 08028 Barcelona, Spain

J. Sánchez Vilas ( $\bowtie)$

Organisms and Environment Division, Cardiff School of Biosciences, Cardiff University, Sir Martin Evans

Building, Cardiff CF10 3AX, UK

e-mail: sanchezvilasj@cardiff.ac.uk content of male and female plants was reduced when growing with Brassica oleracea, but not when growing with conspecifics. In the absence of herbivory, females growing with same-sex neighbour had greater root biomass than males; whilst herbivory reduced root biomass significantly only in females competing with same sex neighbours. Plant damage caused by herbivores was similar when growing with male or female conspecifics but greater when growing with $B$. oleracea. Finally, plant damage caused by herbivores did not differ between male and female plants; however, males increased their allocation to roots and reduced their chlorophyll content after damage. Our results showed that sexual dimorphism occurs in S. oleracea, despite being a worldwide crop, selectively bred for its edible leaves. In particular, our results suggest stronger same-sex competition for females and greater tolerance to herbivory in males than in females of $S$. oleracea..

Keywords Biotic stress - Dioecy - Helix aspersa . Inter- and intra-sexual competition $\cdot$ Sexual dimorphism $\cdot$ Snail grazing

\section{Introduction}

In many dioecious plant species, male and female plants are different not only in their sexual organs but 
also in their morphological, physiological and life history traits. Such sexual dimorphism is typically related to differences in reproductive costs associated with male and female functions (Dawson and Geber 1999; Obeso 2002; Barrett and Hough 2013). Females produce flowers and fruits, and therefore, they usually invest more carbon in reproduction than males. However, in some species, particularly in windpollinated herbs, allocation of certain resources (e.g., nitrogen) to flowers alone may be considerably higher for males (Harris and Pannell 2008). The greater investment of limiting resources to reproduction by one of the sexes may come at the expense of reduced investment of those resources to other functions, such as growth and defence (Obeso 2002). Sex-related differences may be affected by the environmental context (Retuerto et al. 2018), and when experiencing stressful conditions, we may expect the sex with higher investment in reproduction to have reduced performance (Juvany and Munné-Bosch 2015). Particularly, females have been found to perform worse under certain abiotic stress conditions, such as drought or nutrient deficiencies (Leigh and Nicotra 2003; Dawson et al. 2004; Li et al. 2004; Rozas et al. 2009; Zhang et al. 2010; Chen et al. 2010; Zhang et al. 2014). This differential response to the environment may lead to strong sex-ratio biases, threatening populations to decline or become extinct (Petry et al. 2016).

Competition and herbivory are two important biotic factors that can affect growth, reproduction and survival of plants, and ultimately, even the abundance of populations and community composition (Crawley 1989; Belsky 1992; Maron and Crone 2006). Despite these two factors being often studied separately, interactions between them are likely to occur. For example, competition can influence the level of herbivory of a focal plant (Moreira et al. 2017), and in turn herbivory can influence plant-plant competition (Borgström et al. 2016). In dioecious plants, the responses to herbivory have been examined in some detail, and males appear more sensitive to damage than females (Cornelissen and Stiling 2005) although further studies are required (Avila-Sakar and Romanow 2012). Lower damage in females may be related to different trade-offs between growth, reproduction and defence resulting in a greater investment in defensive traits (Agren et al. 1999; Cornelissen and Stiling 2005). In addition, following the optimal defence theory, female reproductive structures should be better defended as they are more valuable for plant fitness (McCall and Fordyce 2010). Differences in the response to competition between males and females may also be expected as a result of the different allocation trade-offs associated with reproduction (e.g., Sánchez-Vilas et al. 2011; Sánchez Vilas and Pannell 2011). If male and female plants demand different resources for reproduction, competition between males and females should be reduced (in comparison with same-sex competition) as a result of niche partitioning (Onyekwelu and Harper 1979). However, data available on competitive abilities of male and female plants are scarce, making it difficult to draw any clear pattern (Mercer and Eppley 2010; Sánchez-Vilas et al. 2011; Varga and Kytöviita 2012; Chen et al. 2014, 2015). Moreover, much less is known about the joint effects of competition and herbivory on the sexes of dioecious plants.

Here, we investigate the competitive ability of male and female plants of the dioecious herb Spinacia oleracea, the cultivated spinach, when growing with another plant of same sex, opposite sex and another species (Brassica oleracea). We also investigate how competition and neighbour identity influence the herbivory damage to male and female plants of $S$. oleracea. S. oleracea is a crop that is grown for its edible leaves, and recent genome and transcriptome analysis have identified domestication signatures for traits such as bolting, flowering, leaf number and stem length (Xu et al. 2017). Therefore, it is plausible that differences between sexes in some of the traits we measured (e.g., above-ground biomass, height) may have been selected against during domestication. Accordingly, we might expect to find little or no sexual dimorphism in those traits for $S$. oleracea.

\section{Materials and methods}

\section{Study species}

Spinacia oleracea L. (Chenopodiaceae) is a windpollinated annual or biannual herb originated in the SW of Asia, being now an important crop grown worldwide and rarely found in the wild. Spinach is easy to grow, and it is considered an example of a recently evolved dioecious species (Onodera et al. 2011) and a potential model system for studies of mechanisms of sex expression and environmental 
influences on gender in dioecious species (Al-Khayri et al. 1991; Sherry et al. 1993; Onodera et al. 2011; Yamamoto et al. 2014). Spinach is also one of the first species where dimorphism between sexual morphs was investigated (Onyekwelu and Harper 1979). Spinach is widely known as dioecious (as referred here); however, cosexual (monoecious) plants can occur in some populations and the sexual system is sometimes termed as trioecious (Vitale and Freeman 1986; Vitale et al. 1987). In our study, frequency of cosexual plants (not included in the study) was very small $(<1 \%)$ and for simplicity we refer to the species as dioecious.

Brassica oleracea L. (Brassicaceae) is one of the most agriculturally important Brassica species. This species is extremely polymorphic and has given rise to many different varieties of unique morphologies and individual crops including broccoli, cabbage, cauliflower, kale, kohlrabi and brussels sprouts (Björkman et al. 2011). Here, in our study, we use wild $B$. oleracea, a perennial commonly found along limestone and chalk cliffs of the British coast (Mitchell and Richards 1979). This species was chosen as the competitor because the time of seedling emergence was similar to that of $S$. oleracea.

\section{Experimental design}

Seeds from Spinacia oleracea L. cv. America were purchased from Thompson and Morgan (Ipswich, England, UK). Seeds from Brassica oleracea $\mathrm{L}$. were collected from wild plants from limestone cliffs on the south coast of Devon, England. Seeds of S. oleracea and $B$. oleracea were sown into germination trays filled with a mix of Verve ${ }^{\mathrm{TM}}$ Multipurpose compost and Brett ${ }^{\mathrm{TM}}$ Horticultural Sand (1:2). One week after germination, seedlings were transplanted into $9 \mathrm{~cm}$ round pots filled with the same mix of compost and sand as above and kept in a glasshouse under long day conditions ( $19 \mathrm{~h}$ light, $5 \mathrm{~h}$ dark). The final experimental design consisted of pots of either one male or one female of S. oleracea (the 'sex' of the focal plant), and the following 'competition' treatments: male $S$. oleracea, female $S$. oleracea and $B$. oleracea. The sex of the plants was, however, unknown at the time of transplanting to allow plants experiencing the effects of competition well before reproduction started. To ensure enough replication, pots with two plants were established in large numbers (a total of 260 pots) and randomly allocated to 12 blocks. Five weeks after germination, all pots with spinach plants in flower were enclosed in perforated bags to exclude (or retain) herbivores and approximately half of the pots were allocated to an 'herbivory' treatment, and the remainder served as controls (see Fig. 1 for schematic diagram with final number of replicates for each 'sex', 'competition' and 'herbivory' treatment). The 'herbivory' treatment involved placing one adult brown garden snail, Helix aspersa (Helicidae), onto the soil at equal distance from plants and left to graze for 10 days. The snails were collected from gardens in Cardiff (Wales, UK) - near the glasshouse facilities of Cardiff University where the experiment took placeand starved for 5 days prior to the experiment. $H$. aspersa is a generalist herbivore that is commonly found on S. oleracea (Miller and Doust 1987).

Leaf damage, growth and biomass allocation

The total number of leaves of each plant was counted before the herbivory treatment. After 10 days of snail grazing, we counted the number of damaged and undamaged leaves. For all damaged leaves, we estimated the proportion of leaf area damaged by herbivory using graph paper and counting missing and total $1 \mathrm{~mm}^{2}$ squares. Leaf damage occurred as holes in most cases, but when leaf margin was missing, damage was estimated by reconstructing the outline of the leaf. We encountered low levels of damage for the vast majority of leaves, hence our method provided rapid but accurate estimations. We then calculated the percentage of plant damage (total proportion of leaf area damaged/total number of leaves $\times 100$ ).

At the end of the experiment, plants were harvested and separated into reproductive organs, roots (belowground biomass, hereafter), and shoots and leaves (above-ground biomass, hereafter). Roots were removed from the soil by washing through a $2 \mathrm{~mm}^{2}$ sieve from which roots were retrieved. In pots with two spinach plants, roots were collected by washing and carefully separating the root systems of both individuals. However, the pattern of growth of $B$. oleracea roots-that were larger than S. oleracea and intertwining with those of $S$. oleracea-did not allow accurate separation of individual roots, and on these pots, roots were measured at pot level. Plant tissues were oven dried at $70{ }^{\circ} \mathrm{C}$ to constant weight and their dry mass recorded. Reproductive effort (RE) was 


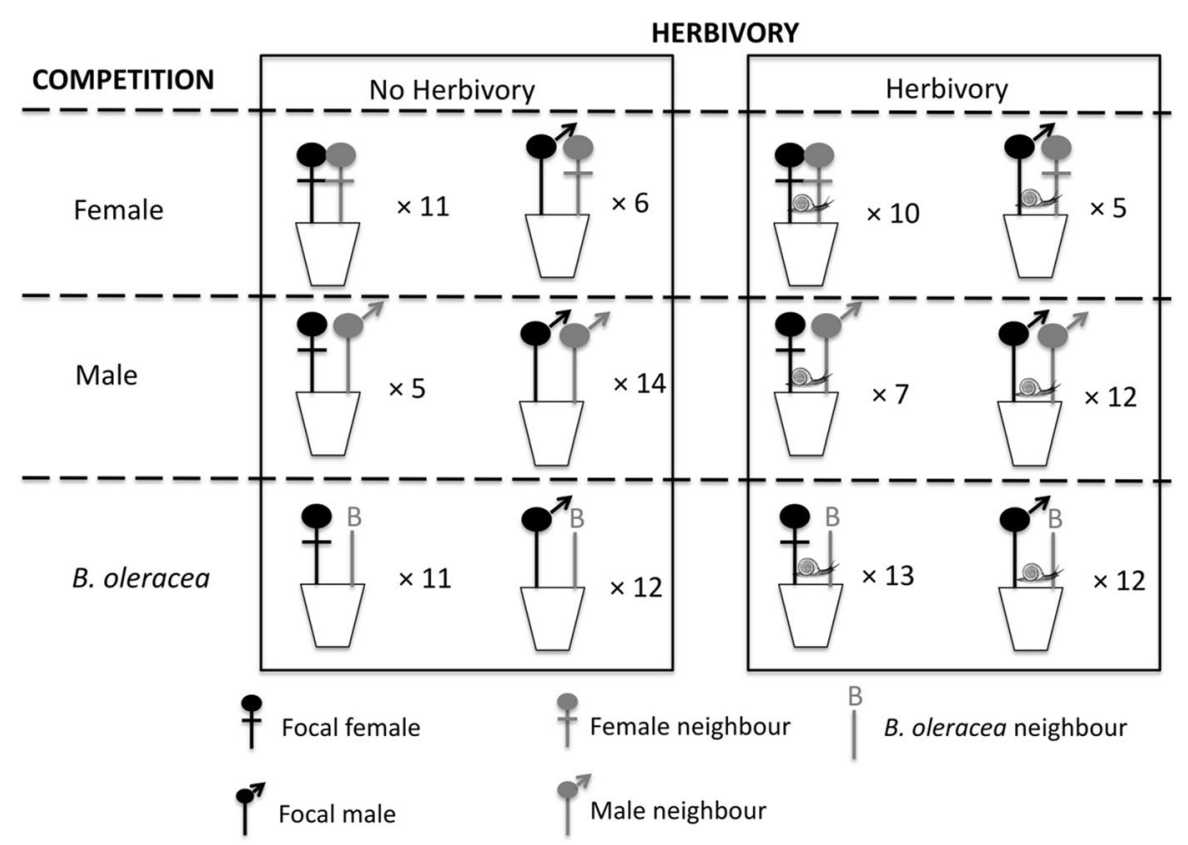

Fig. 1 Schematic representation of the experimental design, consisting of pots of either one male or one female of S. oleracea (the 'sex' of the focal plant, in black symbols), and the following 'competition' treatments: female $S$. oleracea, male $S$. oleracea, B. oleracea (upper, middle and low panels, respectively; neighbours are represented by grey symbols). Five weeks after germination all pots with spinach plants in flower were enclosed in perforated bags to exclude (or retain) herbivores and

calculated by dividing the dry mass allocated to reproduction by vegetative dry mass (roots plus stems and leaves).

\section{Chlorophyll content}

After 7 weeks of growth under the competition treatments, and prior to the start of the 'herbivory' treatment, we measured the chlorophyll content in two young and fully developed leaves per plant (leaves of similar age-growing at the same internode were chosen). The chlorophyll content was also measured 10 days later, at the end of the herbivory treatment, after the snails were removed from the experimental pots. The chlorophyll content was measured using a hand-held chlorophyll meter (SPAD-502, Konica Minolta Inc., Japan), which calculates an index based on absorbance at 650 and $940 \mathrm{~nm}$. SPAD values are well correlated with the chlorophyll content of leaves (Gamon and Surfus 1999; Richardson et al. 2002). approximately half of the pots were allocated to the 'herbivory' treatment, and the remainder served as controls ('no herbivory'). The 'herbivory' treatment involved placing one adult brown garden snail, Helix aspersa (Helicidae) onto the soil at equal distance of plants and left to graze for 10 days. The numbers near the pots indicate the final number of replicates for each 'sex', 'competition' and 'herbivory' treatment

Data analysis

Analyses of growth and biomass allocation (aboveand below-ground biomass, total biomass, reproductive effort (RE) and root: shoot ratio) and chlorophyll content were carried out using linear mixed-effects models using the $\mathrm{R}$ 'Ime' function from the 'nlme' package (Pinheiro et al. 2010). B. oleracea was excluded from the analysis of below-ground biomass and root:shoot ratio because it was difficult to separate roots of competing $S$. oleracea and B. oleracea. Analyses of leaf damage were also carried out using linear mixed-effects models. In pots with two spinach plants, a focal spinach plant (either male or female) was randomly chosen and analyses were run on the above traits for the focal plant. 'Sex', 'competition' and 'herbivory' and their second- and third-order interactions were fitted as fixed factors and block was fitted as random 'blocking' effect to account for potential position effects within the glasshouse. $P$ values were determined by comparing models with and 
without the factor being tested (Crawley 2007). Model comparison was performed by means of likelihood ratio tests by calling the function 'anova' to compare models that, for fixed effects, were fitted using maximum likelihood (Pinheiro and Bates 2000; Crawley 2007). When significant differences, post hoc tests were performed to examine the mean differences among groups using Tukey's HSD tests by means of the 'lsmeans' function in R. Aboveground biomass, total biomass and root:shoot ratio were $\log _{-10}$ transformed and RE and percentage of plant damage were square-root transformed to meet the assumptions of the analysis of variance. All analyses were performed using the computing environment R (R Development Core Team 2014).

\section{Results}

Growth and biomass allocation

Males were taller than females (Sex, Table 1, Fig. 2a), but females had greater above-ground and total biomass than males regardless of competition treatment (Sex, Table 1, and Fig. 2b, c, respectively). Overall, the height and total biomass of the plants (both males and females) were not affected by the identity of the neighbour they were growing with (Competition, Table 1, Fig. 2a, c). The identity of the neighbour had, however, an effect on the aboveground biomass, and particularly, spinach plants (both males and females) growing with $B$. oleracea had less above-ground biomass than those growing with a female or a male neighbour (Competition, Table 1, Fig. 2b). Herbivory treatment and any of the interactions had no effect on height, above-ground and total biomass (Table 1).

The patterns of below-ground biomass were affected by the interaction of sex, competition and herbivory treatments (see Table 1: Sex $\times$ Competition $\times$ Herbivory). In the absence of herbivory, females growing with female neighbours had greater total below-ground biomass than males (Fig. 3a). In addition, herbivory reduced the below-ground biomass of females but in males the trend was the reverse-i.e., males tended to increase their belowground biomass in response to herbivory, although post hoc differences were not statistically significant-(Fig. 3a). In terms of proportional allocation to roots, no differences between the sexes were found in the absence of herbivory, however, males (regardless of the competition treatment) had significantly greater root: shoot ratio than females when exposed to snail grazing (Sex $\times$ H, Table 1, Fig. 3b).

No differences were found in RE between the sexes or as a result of competition and herbivory, or any of the interactions (Table 1).
Table 1 Results of the linear mixed effects model (lme) for the effect competition (none, male $S$. oleracea, female $S$. oleracea, $B$. oleracea), and herbivory (no herbivory, herbivory) on height $(\mathrm{cm})$, above-ground, below-ground and total biomass $(\mathrm{g})$, root/shoot ratio and reproductive effort (RE) of males and females of S. oleracea

\begin{tabular}{|c|c|c|c|c|c|c|c|c|c|c|c|c|c|}
\hline \multirow[t]{2}{*}{ Source of variation } & \multirow[t]{2}{*}{$\mathrm{df}$} & \multicolumn{2}{|c|}{ Height $(\mathrm{cm})$} & \multicolumn{2}{|c|}{$\begin{array}{l}\text { Above-ground } \\
\text { biomass }(\mathrm{g})\end{array}$} & \multicolumn{2}{|c|}{$\begin{array}{l}\text { Below-ground } \\
\text { biomass }(\mathrm{g})\end{array}$} & \multicolumn{2}{|c|}{$\begin{array}{l}\text { Total biomass } \\
(\mathrm{g})\end{array}$} & \multicolumn{2}{|c|}{$\begin{array}{l}\text { Root/shoot } \\
\text { ratio }\end{array}$} & \multicolumn{2}{|l|}{$\mathrm{RE}$} \\
\hline & & $\chi^{2}$ & $P$ & $\chi^{2}$ & $P$ & $\chi^{2}$ & $P$ & $\chi^{2}$ & $P$ & $\chi^{2}$ & $P$ & $\chi^{2}$ & $P$ \\
\hline Sex & 1 & 7.17 & 0.007 & 13.29 & $<0.001$ & - & - & 12.66 & $<0.001$ & - & - & 0.022 & 0.882 \\
\hline Competition (C) & 2 & 1.29 & 0.523 & 10.96 & 0.004 & - & - & 0.01 & 0.921 & 4.59 & 0.101 & 0.259 & 0.878 \\
\hline Herbivory $(\mathrm{H})$ & 1 & 0.003 & 0.955 & 1.82 & 0.177 & - & - & 0.603 & 0.437 & - & - & 0.011 & 0.917 \\
\hline $\operatorname{Sex} \times C$ & 2 & 0.872 & 0.647 & 0.91 & 0.634 & - & - & 0.138 & 0.71 & 1.35 & 0.245 & 0.193 & 0.908 \\
\hline $\operatorname{Sex} \times H$ & 1 & 0.645 & 0.422 & 0.013 & 0.907 & - & - & 1.83 & 0.176 & 4.55 & 0.033 & 0.016 & 0.899 \\
\hline $\mathrm{C} \times \mathrm{H}$ & 2 & 0.709 & 0.701 & 1.56 & 0.458 & - & - & 0.447 & 0.503 & 0.0003 & 0.986 & 0.749 & 0.688 \\
\hline $\mathrm{Sex} \times \mathrm{C} \times \mathrm{H}$ & 2 & 0.733 & 0.693 & 2.43 & 0.297 & 4.34 & 0.037 & 1.33 & 0.248 & 0.533 & 0.465 & 4.24 & 0.12 \\
\hline
\end{tabular}

$P$ values were determined by comparing models with and without the factor being tested by means of likelihood ratio tests following a Chi square distribution ( $\chi^{2}$ : likelihood ratio Chi square statistic). The degrees of freedom (df) are equal to the difference in degrees of freedom of the two models being compared. See text for more details. Significant effects $(P<0.05)$ are indicated in bold. Main effects included in a significant interaction were not tested $(-)$ 


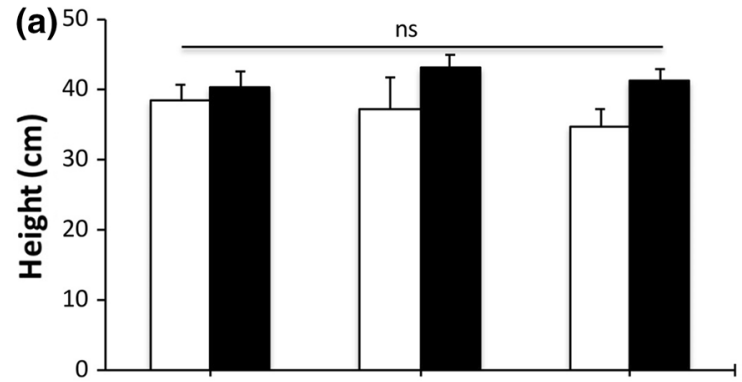

(b)
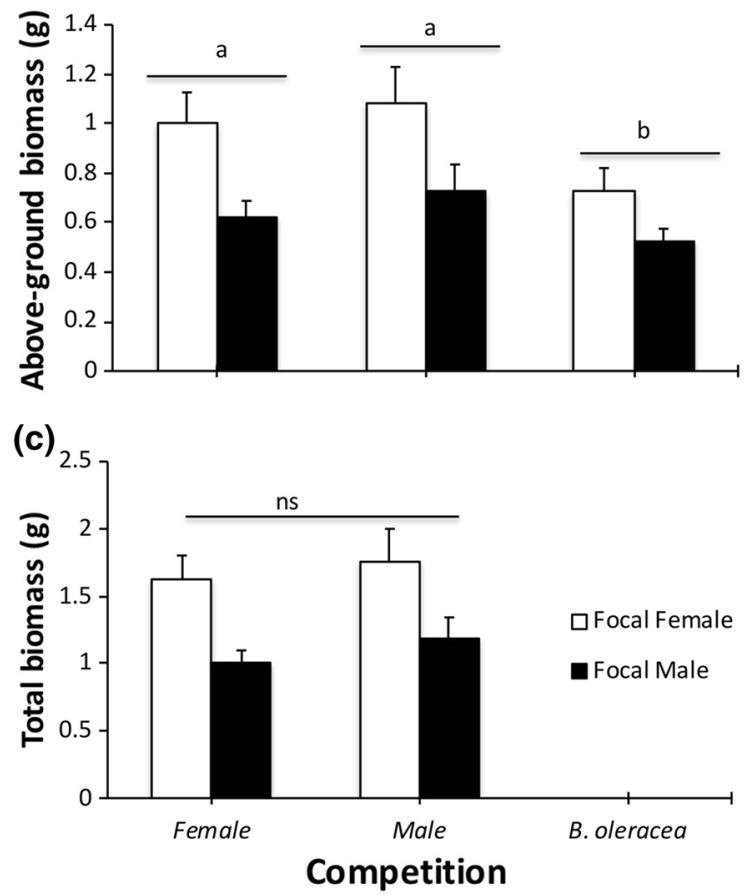

Fig. 2 Height (a), above-ground (b) and total (c) biomass of male and female plants of $S$. oleracea growing alone, with a conspecific male or female, and with an individual of $B$. oleracea. In (c) total biomass of individuals competing with $B$. oleracea is not given, due to the lack of measurements of root biomass (see text for more details). Bars and error bars represent means (female: $N_{\text {female }}=21, N_{\text {male }}=11$, male: $N_{\text {female }}=12$, $N_{\text {male }}=26 ;$ B. oleracea: $N_{\text {female }}=24, N_{\text {male }}=24$ ) and S.E., respectively. Significant differences among the different competition treatments (Female, Male, B. oleracea) are indicated by different letters above the bars $(P<0.05)$ and $n s$ means not significant $(P>0.05)$ based on Tukey HSD

\section{Chlorophyll content}

Females had greater chlorophyll content than males before the herbivory treatment regardless of competition (Sex, Table 2, Fig. 4a, b). The analysis of chlorophyll content pre-herbivory also showed that there were no a priori differences between plants
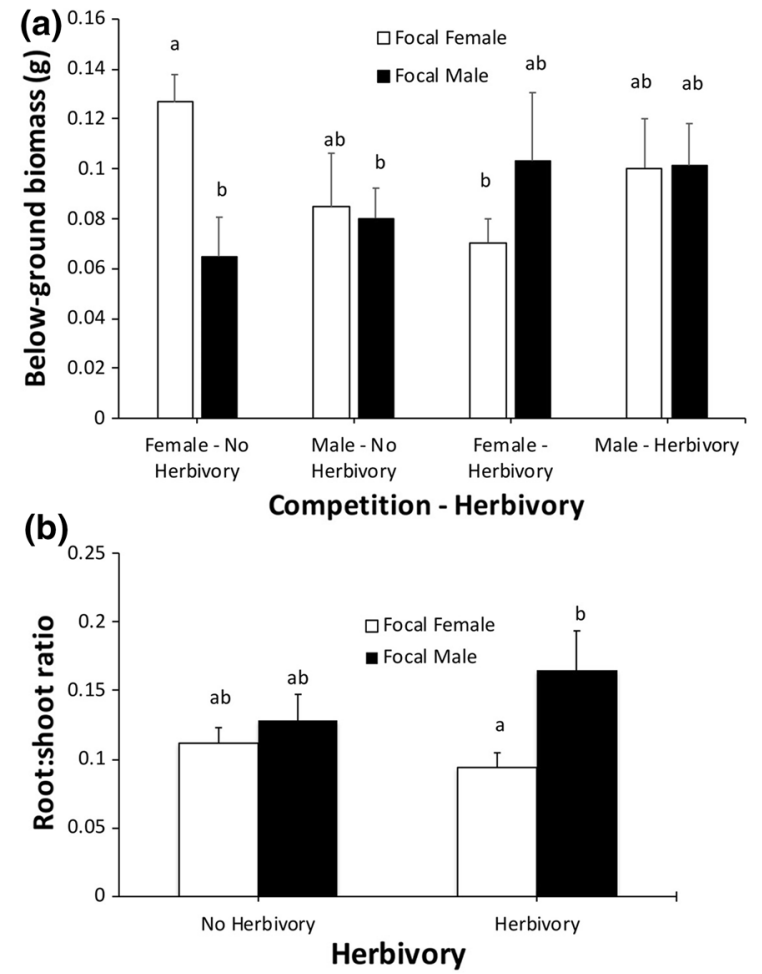

Fig. 3 Below-ground biomass (a) of male and female plants of S. oleracea growing under different competition treatments and exposed or not to snail's herbivory and root:shoot ratio (b) of male and female plants of $S$. oleracea exposed or not to snail's herbivory. Below-ground biomass of individuals competing with B. oleracea is not given, due to the lack of measurements of root biomass (see text for more details). Bars and error bars represent means $\left[(\mathbf{a})=\right.$ 'Female - No herbivory': $\mathrm{N}_{\text {female }}=11$, $\mathrm{N}_{\text {male }}=6$; 'Male-No herbivory': $N_{\text {female }}=5, N_{\text {male }}=14$; ' $\mathrm{Fe}$ male-Herbivory': $N_{\text {female }}=10, N_{\text {male }}=5$; 'Male-Herbivory': $N_{\text {female }}=7, N_{\text {male }}=12 ;$ (b) = 'No herbivory': $N_{\text {female }}=16$, $N_{\text {male }}=20$; 'Herbivory': $\left.N_{\text {female }}=17, N_{\text {male }}=17\right]$ and S.E., respectively. Different letters above the bars indicate significant differences $(P<0.05)$ among the different groups based on Tukey HSD

allocated to no herbivory or herbivory treatments (Table 2; Fig. 4a). However, at harvest, chlorophyll content of males and females was affected differently by snail herbivory (significant interaction sex $\times$ herbivory, Table 2); in particular, no differences in chlorophyll content between males and females were found in the absence of herbivores, but when exposed to snail herbivory, males had a lower chlorophyll content than females (Fig. 4c). In addition, the identity of the neighbour also affected the chlorophyll content (Competition, Table 1), and focal plants (both males 
Table 2 Results of the linear mixed effects model (lme) for the effect competition (male S. oleracea, female $S$. oleracea, $B$. oleracea), and herbivory (no herbivory, herbivory) on the chlorophyll content of leaves pre- and post- herbivory

\begin{tabular}{|c|c|c|c|c|c|c|c|}
\hline \multirow[t]{2}{*}{ Source of variation } & \multirow[t]{2}{*}{$\mathrm{df}$} & \multicolumn{2}{|c|}{$C h l$ content pre-herbivory (SPAD) } & \multicolumn{2}{|c|}{$C h l$ content post-herbivory (SPAD) } & \multicolumn{2}{|c|}{ Plant damage $(\%)$} \\
\hline & & $\chi^{2}$ & $P$ & $\chi^{2}$ & $P$ & $\chi^{2}$ & $P$ \\
\hline Sex & 1 & 4.18 & 0.041 & - & - & 0.025 & 0.874 \\
\hline Competition (C) & 2 & 0.901 & 0.637 & 10.91 & 0.004 & 8.48 & 0.014 \\
\hline Herbivory $(\mathrm{H})$ & 1 & 0.116 & 0.733 & - & - & N/A & N/A \\
\hline $\operatorname{Sex} \times C$ & 2 & 0.989 & 0.61 & 2.02 & 0.365 & 2.35 & 0.309 \\
\hline $\operatorname{Sex} \times \mathrm{H}$ & 1 & 0.055 & 0.813 & 4.53 & $\mathbf{0 . 0 3 3}$ & N/A & N/A \\
\hline $\mathrm{C} \times \mathrm{H}$ & 2 & 1.16 & 0.56 & 2.77 & 0.251 & N/A & N/A \\
\hline $\operatorname{Sex} \times \mathrm{C} \times \mathrm{H}$ & 2 & 3.21 & 0.2 & 1.66 & 0.435 & N/A & N/A \\
\hline
\end{tabular}

$P$ values were determined by comparing models with and without the factor being tested by means of likelihood ratio tests following a Chi square distribution ( $\chi^{2}$ : likelihood ratio Chi square statistic). The degrees of freedom (df) are equal to the difference in degrees of freedom of the two models being compared See text for more details. Significant effects $(P<0.05)$ are indicated in bold. Main effects included in a significant interaction were not tested (-). N/A (terms not applicable to the model tested)

and females) had the lowest chlorophyll content when growing with a $B$. oleracea plant (Fig. 4d).

\section{Plant damage}

Males and females had similar levels of herbivory (Sex, Table 2). However, the identity of the neighbour had a significant effect on plant damage (Competition, Table 2). In particular, no significant differences in the level of damage were found between plants of spinach (both male and female plants) growing with conspecifics (either same or opposite sex) (Fig. 5). However, the percentage of damage was significantly greater when plants had a $B$. oleracea neighbour (Fig. 5).

\section{Discussion}

Overall, male plants were taller than female plants, whilst females had greater biomass. Such differences remained regardless competition and herbivory treatments, i.e., males grew taller than females and females had more biomass when growing with conspecifics (either another male or female) and with individuals of another species. The greater height in males of $S$. oleracea may be expected as a result of selection to maximize pollen dispersal in a wind-pollinated species (Friedman and Barrett 2009); pollen can travel longer distances if released at greater heights (Burd treatment of males and females S. oleracea; and the effect of competition on the level of herbivory (Plant damage, \%) of male and female plants 

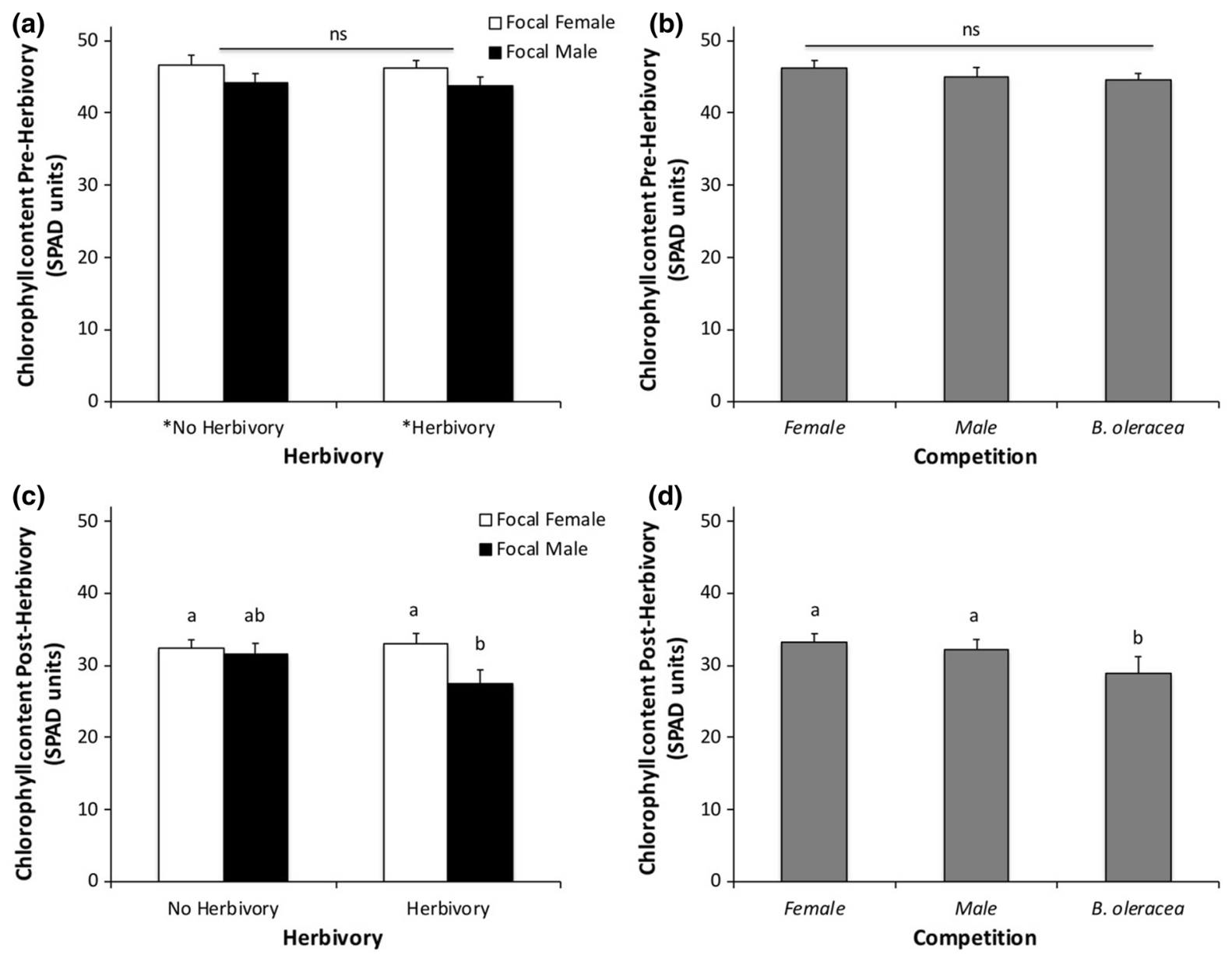

Fig. 4 Chlorophyll content (SPAD units) of male and female plants of $S$. oleracea in plants allocated to the herbivory treatments and in response to competition prior to $(\mathbf{a}, \mathbf{b}$, respectively) and after (c, d, respectively) exposure to snail's herbivory. Note that in (a) the '*No Herbivory' and '*Herbivory' groups refer only to the allocation of plants to each treatment prior to the exposure to snail's herbivory. Bars and

growing with same sex neighbour-had greater root biomass than males. As explained above for aboveground biomass, the greater total allocation to roots in females may also be the result of differences in the partitioning of resources to vegetative and reproductive tissues (Sklensky and Davies 2011). As females of S. oleracea have greater above-ground biomass than males (and also greater chlorophyll content), greater roots allow maximizing resource uptake below ground to sustain their growth (Sánchez Vilas and Pannell 2011). In general, plants have been found to proliferate more roots when experiencing intense competition for nutrients (Craine 2006). Our study does not include a

error bars represent means (a, $\mathbf{c}=$ No Herbivory: $N_{\text {female }}=27$, $N_{\text {male }}=32$; Herbivory: $N_{\text {female }}=30, N_{\text {male }}=29 ; \mathbf{b}, \mathbf{d}=N_{\text {fe- }}$ male $=32, N_{\text {male }}=38, N_{B}$. oleracea $\left.=48\right)$ and S. E., respectively. Different letters above the bars indicate significant differences $(P<0.05)$ among the different groups and ns indicates not significant differences $(P>0.05)$ based on Tukey HSD

control for competition (i.e., plants without neighbours), however, the greater root biomass seen for females growing with same-sex neighbour may respond to their greater competition for below-ground nutrients. In dioecious species, if male and female plants differ in resource acquisition, competition between the sexes would be reduced; however, same-sex competition would potentially increase-as seen here for females-(Onyekwelu and Harper 1979). Moreover, if sexes have different uptake of resources from the soil, this may eventually lead to differences in resource availability (Sánchez Vilas and Pannell 2010), which in turn is known to alter the 


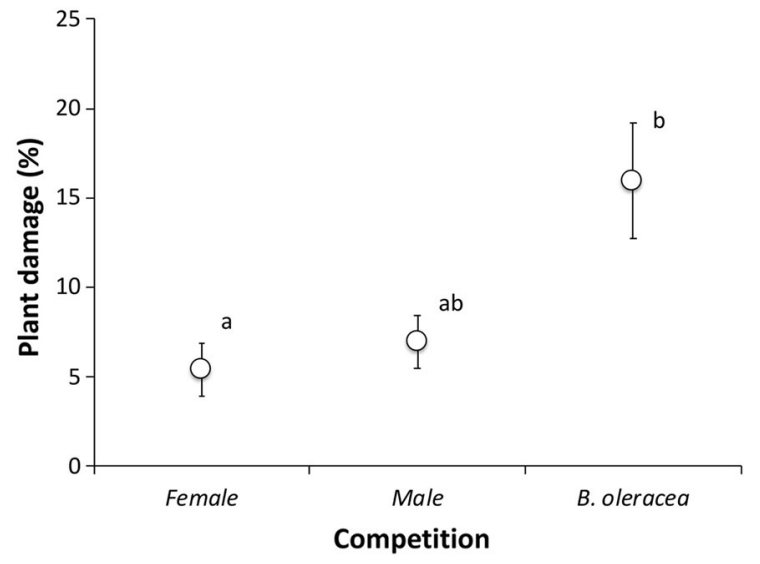

Fig. 5 Percentage of plant damage in plants of S. oleracea after exposure to snails' herbivory when growing with a conspecific female $(N=15)$ or male $(N=19)$, and with an individual of $B$. oleracea $(N=25)$. Bars and error bars represent means and SE, respectively. Different letters above the bars indicate significant differences $(P<0.05)$ among the different groups and ns indicates not significant differences $(P>0.05)$ based on Tukey HSD

outcome of competition between the sexes. For example, in Populus cathayana high-nitrogen conditions intensified competition between the sexes, whilst low-nitrogen conditions intensified same-sex competition in female (Chen et al. 2015). This result will therefore suggest sexual dimorphism in response to competition, as found in previous studies (SánchezVilas et al. 2011; Hesse and Pannell 2011; Varga and Kytöviita 2012; Chen et al. 2014). Patterns of belowground biomass in males and females were also affected by herbivory. In particular, we found that herbivory reduced root biomass in females; the greatest reduction seen when females were growing with same-sex neighbour. Patterns of response to herbivory are complex, involving whole-plant responses such as changes in reallocation of resources (Gómez et al. 2010; Orians et al. 2011). Although many plants increase their allocation to storage tissues (e.g., roots) in response to herbivory, investment in new growth may be favoured under certain conditions (Orians et al. 2011). It is plausible that females under intense competition below-ground and with rapid growth above-ground may invest more in current growth to sustain reproduction rather than storage to roots. Alternatively, the stronger response of females to same sex competition may also suggest the existence of sex recognition. Recently, root-mediated sex recognition has been suggested in the dioecious tree Populus cathayana, with different responses in root growth and allocation depending on the sex of the neighbours (Dong et al. 2017). It could be argued that a similar mechanism may be responsible for the observed response in our study, but further empirical evidence would be required to support this hypothesis.

The percentage of plant damage due to snail grazing was different on the focal plant depending on whether they were growing with conspecifics or $B$. oleracea individuals (greater damage when growing with $B$. oleracea). Our experiment involved an element of choice, as both focal and neighbouring plants were enclosed with a single snail. Therefore, differences in preferential feeding due, for example, to differences in plant quality and/or defences may have contributed to this result. Competition with $B$. oleracea reduced the above-ground biomass and also the chlorophyll content of both male and female plants of $S$. oleracea, which suggests this species has a greater competitive ability than $S$. oleracea (Tilman 1982). If $B$. oleracea outcompetes $S$. oleracea for resources, this could reduce the investment of $S$. oleracea in antiherbivore defences and in turn make it more susceptible to herbivore damage (Kim and Underwood 2015). In addition, although male and female plants experienced the same levels of herbivory damage above ground, herbivory influenced the chlorophyll content and the patterns of allocation to below-ground biomass in males and females. At the time of the harvest, no differences in chlorophyll content were found between males and females in the absence of herbivory, but the chlorophyll content of males was lower than that of females in response to snail grazing. Chlorophyll content is usually closely linked to nitrogen status (Bojović and Marković 2009; Brunetto et al. 2012; Gholizadeh et al. 2017), and at the time of the harvest, males were flowering, which in windpollinated herbs involves producing high amounts of N-rich pollen (Ishida et al. 2005; Kerkhoff et al. 2006). Therefore, it may be possible that the observed results are the consequence of trade-offs between allocation to growth, reproduction and defence: males investing more $\mathrm{N}$ in reproduction than females and having to invest in defences may compromise allocation to growth as indicated by their lower chlorophyll content (Harris and Pannell 2008). The lower chlorophyll content in leaves of males under herbivory could also be the result of reallocation of resources $(\mathrm{N}$ in this 
case) from leaves to roots in response to damage, which then could contribute to compensatory growth (Gómez et al. 2010; Orians et al. 2011; Korpita et al. 2014; Kornelsen and Avila-Sakar 2015). Although no differences in damage were found between the sexes, the lower $\mathrm{N}$ content in leaves might eventually reduce the level of damage in males, as herbivores prefer tissues with greater N content (Mattson 1980). Herbivory damage above ground, as indicated above, reduced root biomass in females but not in males; as a result, the root: shoot ratio of males was greater than that of females in response to snail grazing. Greater proportional root allocation, i.e., higher root: shoot ratios, has been previously associated with responses to above-ground herbivory, and has been suggested as a mechanism that allows plants to be more competitive, which eventually may allow plants to compensate for tissue losses due to herbivory (Schmidt 2007). Our results, therefore, would indicate a greater tolerance to herbivory by males than females in $S$. oleracea.

In conclusion, we found sexual dimorphism in growth in S. oleracea consistent with patterns found in other wind-pollinated dioecious species. Our results indicate stronger inter- than intra-specific competition in spinach; and our data on below-ground biomass suggest different response to competition in males and females, with stronger same-sex competition in females. Percentage of plant damage was similar in both sexes; however, our results indicate sexual dimorphism in response to herbivory in terms of chlorophyll content and below-ground biomass. Males appear to have a greater tolerance to herbivory, as suggested by the greater proportional allocation to roots after damage in this sex. Overall, our findings highlight the complexity of multiple interactions in sex-specific responses and also the different strategies of the sexes during plant growth under competition and herbivory.

Acknowledgements We thank Mr Lyndon Tuck for his invaluable assistance in setting up and looking after the experiments at the growth plant facilities in Talybont. We thank Prof. Golenberg for his advice on growing S. oleracea var. America. We thank Prof. Pannell and two anonymous reviewers for their useful advice to an earlier draft of this manuscript. We also thank the Erasmus + Program for a mobility grant to M.P.Ll.

Open Access This article is distributed under the terms of the Creative Commons Attribution 4.0 International License (http:// creativecommons.org/licenses/by/4.0/), which permits unrestricted use, distribution, and reproduction in any medium, provided you give appropriate credit to the original author(s) and the source, provide a link to the Creative Commons license, and indicate if changes were made.

\section{References}

Agren J, Danell K, Elmqvist T (1999) Sexual dimorphism and biotic interactions. In: Geber MA, Dawson TE, Delph LF (eds) Gender and sexual dimorphism in flowering plants. Springer, New York, pp 217-246

Al-Khayri JM, Huang FH, Morelock TE, Lane FE (1991) In vitro flowering in regenerated shoots of spinach. HortScience 26:1422

Avila-Sakar G, Romanow CA (2012) Divergence in defence against herbivores between males and females of dioecious plant species. Int J Evol Biol 2012:897157. https://doi.org/ $10.1155 / 2012 / 897157$

Barrett SCH, Hough J (2013) Sexual dimorphism in flowering plants. J Exp Bot 64:67-82. https://doi.org/10.1093/jxb/ ers308

Belsky AJ (1992) Effects of grazing, competition, disturbance and fire on species composition and diversity in grassland communities. J Veg Sci 3:187-200. https://doi.org/10. 2307/3235679

Björkman M, Klingen I, Birch A (2011) Phytochemicals of Brassicaceae in plant protection and human health-influences of climate, environment and agronomic practice. Phytochemistry 7:538-556

Bojović B, Marković A (2009) Correlation between nitrogen and chlorophyll content in wheat (Triticum aestivum L.). Kragujev J Sci 31:69-74

Borgström P, Strengbom J, Viketoft M, Bommarco R (2016) Aboveground insect herbivory increases plant competitive asymmetry, while belowground herbivory mitigates the effect. PeerJ 4:e1867. https://doi.org/10.7717/peerj.1867

Brunetto G, Trentin G, Ceretta CA, Girotto E, Lorensini F, Miotto A, Regina G, Moser Z, De Melo GW (2012) Use of the SPAD-502 in estimating nitrogen content in leaves and grape yield in grapevines in soils with different texture. Am J Plant Sci 3:1546-1561. https://doi.org/10.4236/ajps. 2012.311187

Burd M, Allen T (1988) Sexual allocation strategy in windpollinated plants. Evolution (N Y) 42:403-407

Chen L, Zhang S, Zhao H, Korpelainen H, Li C (2010) Sexrelated adaptive responses to interaction of drought and salinity in Populus yunnanensis. Plant, Cell Environ 33:1767-1778. https://doi.org/10.1111/j.1365-3040.2010. 02182.x

Chen J, Duan B, Wang M, Korpelainen H, Li C (2014) Intra- and inter-sexual competition of Populus cathayana under different watering regimes. Funct Ecol 28:124-136. https:// doi.org/10.1111/1365-2435.12180

Chen J, Dong T, Duan B, Korpelainen H, Niinemets Ü, Li C (2015) Sexual competition and N supply interactively affect the dimorphism and competiveness of opposite sexes 
in Populus cathayana. Plant, Cell Environ 38:1285-1298. https://doi.org/10.1111/pce. 12477

Cornelissen T, Stiling P (2005) Sex-biased herbivory: a metaanalysis of the effects of gender on plant-herbivore interactions. Oikos 111:488-500

Craine JM (2006) Competition for nutrients and optimal root allocation. Plant Soil 285:171-185. https://doi.org/10. 1007/s11104-006-9002-x

Crawley MJ (1989) Insect herbivores and plant population dynamics. Annu Rev Entomol 34:531-562. https://doi.org/ 10.1146/annurev.en.34.010189.002531

Crawley MJ (2007) The R book. Wiley, Chichester

Dawson TE, Geber MA (1999) Sexual dimorphism in physiology and morphology. In: Geber MA, Dawson TE, Delph LF (eds) Gender and sexual dimorphism in flowering plants. Springer, New York, pp 175-215

Dawson TE, Ward JK, Ehleringer JR (2004) Temporal scaling of physiological responses from gas exchange to tree rings: a gender-specific study of Acer negundo (Boxelder) growing under different conditions. Funct Ecol 18:212-222. https://doi.org/10.1111/j.0269-8463.2004. 00838.x

Delph LF, Meagher TR (1995) Sexual dimorphism masks life history trade-offs in the dioecious plant Silene latifolia. Ecology 76:775-785. https://doi.org/10.2307/1939343

Dong T, Li J, Yongmei L, Chen BJW, Xu X (2017) Root-mediated sex recognition in a dioecious tree. Sci Rep 7:801

Friedman J, Barrett SCH (2009) Wind of change: new insights on the ecology and evolution of pollination and mating in wind-pollinated plants. Ann Bot 103:1515-1527. https:// doi.org/10.1093/aob/mcp035

Gamon JA, Surfus JS (1999) Assessing leaf pigment content and activity with a reflectometer. New Phytol 143:105-117. https://doi.org/10.1046/j.1469-8137.1999.00424.x

Gholizadeh A, Saberioon M, Borůvka L, Wayayok A, Mohd Soom MA (2017) Leaf chlorophyll and nitrogen dynamics and their relationship to lowland rice yield for site-specific paddy management. Inf Process Agric 4:259-268. https:// doi.org/10.1016/J.INPA.2017.08.002

Gómez S, Ferrieri RA, Schueller M, Orians CM (2010) Methyl jasmonate elicits rapid changes in carbon and nitrogen dynamics in tomato. New Phytol 188:835-844. https://doi. org/10.1111/j.1469-8137.2010.03414.x

Harris MS, Pannell JR (2008) Roots, shoots and reproduction: sexual dimorphism in size and costs of reproductive allocation in an annual herb. Proc R Soc B Biol Sci B 275:2595-2602. https://doi.org/10.1098/rspb.2008.0585

Hesse E, Pannell JR (2011) Sexual dimorphism in a dioecious population of the wind-pollinated herb Mercurialis annиa: the interactive effects of resource availability and competition. Ann Bot 107:1039-1045. https://doi.org/10.1093/ aob/mcr046

Ishida TA, Hattori K, Shibata S, Suzuki M, Kimura MT (2005) Sex allocation of a cosexual wind-pollinated tree, Quercus dentata, in terms of four currencies. J Plant Res 118:193-197. https://doi.org/10.1007/s10265-005-0206-6

Juvany M, Munné-Bosch S (2015) Sex-related differences in stress tolerance in dioecious plants: a critical appraisal in a physiological context. J Exp Bot 66:6083-6092. https:// doi.org/10.1093/jxb/erv343
Kerkhoff AJ, Fagan WF, Elser JJ, Enquist BJ (2006) Phylogenetic and growth form variation in the scaling of nitrogen and phosphorus in the seed plants. Am Nat 168:E103E122. https://doi.org/10.1086/507879

Kim TN, Underwood N (2015) Plant neighborhood effects on herbivory: damage is both density and frequency dependent. Ecology 96:1431-1437

Kornelsen J, Avila-Sakar G (2015) Ontogenetic changes in defence against a generalist herbivore in Arabidopsis thaliana. Plant Ecol 216:847-857. https://doi.org/10.1007/ s11258-015-0472-x

Korpita T, Gómez S, Orians CM (2014) Cues from a specialist herbivore increase tolerance to defoliation in tomato. Funct Ecol 28:395-401. https://doi.org/10.1111/1365-2435. 12184

Leigh A, Nicotra AB (2003) Sexual dimorphism in reproductive allocation and water use efficiency in Maireana pyramidata (Chenopodiaceae), a dioecious, semi-arid shrub. Aust J Bot 51:509-514

Li C, Ren J, Luo J, Lu R (2004) Sex-specific physiological and growth responses to water stress in Hippophae rhamnoides L. populations. Acta Physiol Plant 26:123-129. https://doi. org/10.1007/s11738-004-0001-3

Maron JL, Crone E (2006) Herbivory: effects on plant abundance, distribution and population growth. Proc Biol Sci 273:2575-2584. https://doi.org/10.1098/rspb.2006.3587

Mattson WJ (1980) Herbivory in relation to plant nitrogen content. Annu Rev Ecol Syst 11:119-161. https://doi.org/ 10.1146/annurev.es.11.110180.001003

McCall AC, Fordyce JA (2010) Can optimal defence theory be used to predict the distribution of plant chemical defences? J Ecol 98:985-992

Mercer CA, Eppley SM (2010) Inter-sexual competition in a dioecious grass. Oecologia 164:657-664. https://doi.org/ 10.1007/s00442-010-1675-4

Miller J, Doust JL (1987) The effects of plant density and snail grazing on female and male spinach plants. New Phytol 107:613-621. https://doi.org/10.1111/j.1469-8137.1987. tb02931.x

Mitchell ND, Richards AJ (1979) Brassica oleracea L. ssp. oleracea (B. sylvestris (L.) Miller). J Ecol 67:1087-1096. https://doi.org/10.2307/2259229

Moreira X, Glauser G, Abdala-Roberts L (2017) Interactive effects of plant neighbourhood and ontogeny on insect herbivory and plant defensive traits. Sci Rep 7:4047. https://doi.org/10.1038/s41598-017-04314-3

Obeso JR (2002) The cost of reproduction in plants. New Phytol 155:321-348. https://doi.org/10.1046/j.1469-8137.2000. 00571.X

Onodera Y, Yonaha I, Masumo H, Tanaka A, Niikura S, Yamazaki S, Mikami T (2011) Mapping of the genes for dioecism and monoecism in Spinacia oleracea L.: evidence that both genes are closely linked. Plant Cell Rep 30:965-971. https://doi.org/10.1007/s00299-010-0998-2

Onyekwelu SS, Harper JL (1979) Sex ratio and niche differentiation in spinach (Spinacia oleracea L.). Nature 282:609-611. https://doi.org/10.1038/282609a0

Orians CM, Thorn A, Gómez S (2011) Herbivore-induced resource sequestration in plants: why bother? Oecologia 167:1-9. https://doi.org/10.1007/s00442-011-1968-2 
Petry WK, Soule JD, Iler AM, Chicas-Mosier A, Inouye DW, Miller TEX, Mooney KA (2016) Sex-specific responses to climate change in plants alter population sex ratio and performance. Science 353:69-71. https://doi.org/10.1126/ science.aaf 2588

Pickup M, Barrett SCH (2012) Reversal of height dimorphism promotes pollen and seed dispersal in a wind-pollinated dioecious plant. Biol Lett 8:245-248. https://doi.org/10. 1098/rsbl.2011.0950

Pinheiro JC, Bates DM (2000) Mixed-effects models in S and S-plus. Springer, New York

Pinheiro J, Bates D, DebRoy S (2010) nlme: linear and nonlinear mixed effects models. Austria, Vienna

R Development Core Team (2014) R: a language and environment for statistical computing

Retuerto R, Sánchez Vilas J, Varga S (2018) Sexual dimorphism in response to stress. Environ Exp Bot 146:1-4

Richardson AD, Duigan SP, Berlyn GP (2002) An evaluation of noninvasive methods to estimate foliar chlorophyll content. New Phytol 153:185-194. https://doi.org/10.1046/j. 0028-646X.2001.00289.x

Rozas V, DeSoto L, Olano JM (2009) Sex-specific, age-dependent sensitivity of tree-ring growth to climate in the dioecious tree Juniperus thurifera. New Phytol 182:687-697. https://doi.org/10.1111/j.1469-8137.2009. 02770.x

Sánchez Vilas J, Pannell JR (2010) Differential niche modification by males and females of a dioecious herb: extending the Jack Sprat effect. J Evol Biol 23:2262-2266. https:// doi.org/10.1111/j.1420-9101.2010.02089.x

Sánchez Vilas J, Pannell JR (2011) Sexual dimorphism in resource acquisition and deployment: both size and timing matter. Ann Bot 107:119-126. https://doi.org/10.1093/ aob/mcq209

Sánchez-Vilas J, Turner A, Pannell JR (2011) Sexual dimorphism in intra- and interspecific competitive ability of the dioecious herb Mercurialis annua. Plant Biol 13:218-222. https://doi.org/10.1111/j.1438-8677.2010.00408.x

Schmidt JP (2007) Sex ratio and spatial pattern of males and females in the dioecious sandhill shrub, Ceratiola ericoides ericoides (Empetraceae) Michx. Plant Ecol 196:281-288. https://doi.org/10.1007/s11258-007-9353-2

Sherry RA, Eckard KJ, Lord EM (1993) Flower development in dioecious Spinacia oleracea (Chenopodiaceae). Am J Bot 80:283-291. https://doi.org/10.2307/2445351
Sklensky DE, Davies PJ (2011) Resource partitioning to male and female flowers of Spinacia oleracea L. in relation to whole-plant monocarpic senescence. J Exp Bot 62:4323-4336. https://doi.org/10.1093/jxb/err148

Tilman D (1982) Resource competition and community structure. Princeton University Press, Princeton

Varga S, Kytöviita M-M (2012) Differential competitive ability between sexes in the dioecious Antennaria dioica (Asteraceae). Ann Bot 110:1461-1470. https://doi.org/10.1093/ aob/mcs 170

Vitale JJ, Freeman DC (1985) Secondary sex characteristics in Spinacia oleracea L.: quantitative evidence for the existence of at least three sexual morphs. Am J Bot 72:1061-1066. https://doi.org/10.2307/2443449

Vitale JJ, Freeman DC (1986) Partial niche separation in Spinacia oleracea L.: an examination of reproductive allocation. Evolution (N Y) 40:426-430. https://doi.org/10. 1111/j.1558-5646.1986.tb00484.x

Vitale JJ, Freeman DC, Merlotti LA, D’Alessandro M (1987) Patterns of biomass allocation in Spinacia oleracea (Chenopodiaceae) across a salinity gradient: evidence for a niche separation. Am J Bot 74:1049-1054. https://doi.org/ $10.2307 / 2443944$

Xu C, Jiao C, Sun H, Cai X, Wang X, Ge C, Zheng Y, Liu W, Sun X, Xu Y, Deng J, Zhang Z, Huang S, Dai S, Mou B, Wang Q, Fei Z, Wang Q (2017) Draft genome of spinach and transcriptome diversity of 120 Spinacia accessions. Nat Commun 8:15275. https://doi.org/10.1038/ ncomms 15275

Yamamoto K, Oda Y, Haseda A, Fujito S, Mikami T, Onodera Y (2014) Molecular evidence that the genes for dioecism and monoecism in Spinacia oleracea L. are located at different loci in a chromosomal region. Heredity (Edinb) 112:317-324. https://doi.org/10.1038/hdy.2013.112

Zhang S, Chen F, Peng S, Ma W, Korpelainen H, Li C (2010) Comparative physiological, ultrastructural and proteomic analyses reveal sexual differences in the responses of Populus cathayana under drought stress. Proteomics 10:2661-2677. https://doi.org/10.1002/pmic.200900650

Zhang S, Jiang H, Zhao H, Korpelainen H, Li C (2014) Sexually different physiological responses of Populus cathayana to nitrogen and phosphorus deficiencies. Tree Physiol 34:343-354. https://doi.org/10.1093/treephys/tpu025 